\title{
Nautical tourism - the advantages and effects of development
}

\author{
S. Favro \& Z. Gržetić \\ Hydrographic Institute of the Republic of Croatia, Croatia
}

\begin{abstract}
In the last thirty years, when a more significant development of nautical tourism in Croatia started, nautical tourism has proved to be one of the most propulsive and stable forms of tourism. Using its comparative advantages, nautical tourism attracts the most demanding clients and initiates a number of accompanying business activities and foreign investments. The positive effects of nautical tourism are evident at all levels, from national to local, but also at the level of business activities. Besides a series of indisputable and clear economic and social benefits realised during the development of nautical tourism and its effects, such a development led to a number of disadvantages. Possible negative effects of marinas to the marine environment and its living world necessitate harmonisation of the development of nautical tourism with other priorities, all based on the principles of sustainable development. One of the significant priorities of Croatia is environment protection. When compared to other categories of dispersed sources of pollution/contamination from urban settlements and agriculture, marinas and nautical tourism cannot be characterised as significant sources of dispersed pollution. However, marinas and nautical tourism may lead to a decrease of the seawater quality from the local aspect and to a negative influence on biological communities of marine organisms and ecosystems. Strict observance of the principles of sustainable development through implementation of the current regulations and laws related to environment protection may ensure that marinas be a guarantor of the preservation of natural values of the water area.
\end{abstract}

Keywords: nautical tourism, environment, sustainable development, spatial planning, yacht pollution, marine environment, systematic development. 


\section{Natural characteristics of the Croatian Adriatic}

The Mediterranean Sea is part of the Atlantic Ocean, situated between three continents of the Old World. With its well-indented and gentle coastline and mild climate it has always offered favourable sailing conditions, as no other sea in the world. Considering this, it is not unexpected that it became "the cradle of maritime affairs" and that some of the world's oldest cultural focal points expanded right here. Croatia has ideal conditions for nautical tourism development, and it has a great number of comparative advantages over the majority of other Mediterranean countries. These advantages are better coastline indentedness, a greater number of well arranged and sheltered ports, better geographical position in relation to countries that nautical tourists come from, better preserved nature, and cleaner sea. Croatia has one of the most beautiful and most indented coastlines in the world. The Adriatic Sea, its coastline and islands, whose values have been recognized on a global scale, should be at the forefront of economic development of Croatia, particularly of coastal and insular development. However, that most important natural resource of our country has not been economically evaluated in the right way, and the past development has not been oriented toward environment protection. Certain parts of that resource are saturated by tourism during the summer, so further development of that area should be directed in accordance with principles of sustainable development.

\section{Nautical tourism in Croatia - past development}

The beginnings of nautical tourism on the Croatian coast date between the two world wars. At that time boaters were using services of the existing ports on land and on the islands. It was only late in the 1960s that the planning of building ports for nautical tourists only started. The first interval of construction of marinas lasted from 1975 to 1984 , and during that interval 19 marinas with 4.466 sea berths were built. Individual developmental initiatives were characteristic for that interval, while the system of nautical tourist supply still did not exist. The second interval of construction of marinas was marked by planned development, thanks to the establishment of the "Adriatic Club Yugoslavia" in 1983 (which is now the ACI). In this way, 20 more marinas with 5.814 sea berths were built between 1984 and 1990. In the interval from 1993 up to this day the development was slow and unplanned and based only on private initiatives. Statistical data for 2004 shows that there are 83 ports of nautical tourism on the Croatian coast of the Adriatic. 50 of them are marinas and 33 are anchorages, moorings and dry marinas. In those 83 ports of nautical tourism there are altogether 20925 berths, 15407 of which are sea berths and 5518 berths on land (dry berths). Except for ports of nautical tourism, there are also more than 300 ports, little ports and bays evenly arranged along the coastline of the land and the islands. 


\section{Advantages and effects of nautical tourism development}

In the last thirty years, when more significant development of nautical tourism in Croatia started (primarily evident in the initial development of marinas), nautical tourism has proved to be one of the most propulsive and stable forms of tourism. During the Croatian War of Independence nautical tourism was almost the only one that survived, even though it was on a reduced scale, unlike other forms of tourist activities that - for obvious reasons - suffered a larger or smaller decrease. The number of nautical tourist arrivals is constantly growing from one year to the next, as well as the number of vessels whose home ports are Croatian marinas.

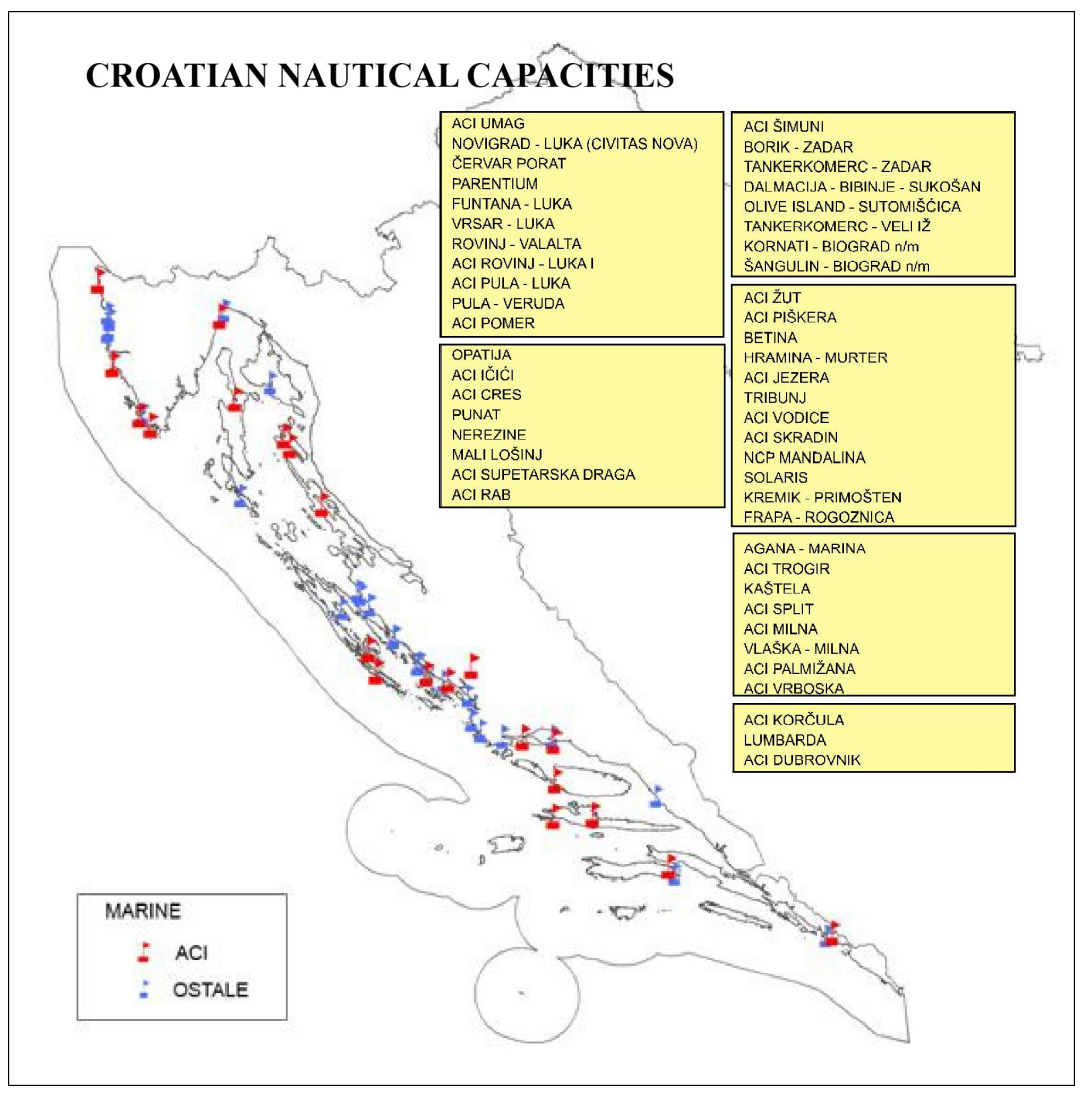

Figure 1: Ports of nautical tourism in Croatia.

By using its comparative advantages, nautical tourism can attract the most demanding clients and initiate a number of accompanying business activities and foreign investments (Favro and Saganić [1]). The development of charter nautical tourism also contributed to nautical tourism development in Croatia. 
The positive effects of nautical tourism are evident at all levels, from national to local, but also at the level of business activities. Through nautical tourism development, the country represented itself not only as a strong and unquestionable nautical destination, but also as an increasingly important tourist destination. For certain counties and more importantly for certain local coastal and insular communities, nautical tourism development means not only a new quality of the entire tourist development, but also an entire series of economic effects that would not be possible without it.

The effects of nautical tourism on particular complementary economic activities that form the nautical economy are especially important. When we are talking of the effects of nautical tourism on tourism as a whole, it includes all those activities or areas of economy and their parts that are directly or indirectly connected with tourism (Žabica [2]):

- marinas

- boat charters

- construction and repair of boats

- retail trade

- hotels and restaurants

- $\quad$ transport, especially air transport

- $\quad$ and an entire series of other activities.

The most important effects of nautical tourism development occurred at local levels, i.e. in certain towns, especially on islands. Considering the fact that islands are physically isolated, due to their geographical position, and often socially isolated and treated as isolated communities, one of the most important effects of nautical tourism occurred in positive terms on islands. Generally speaking, it can be said that tourism has positive influence on the development of islands (Kozak and Rimmington [3]). Since the life on islands goes on - most of the time - according to the principle of "limited resource", nautical visiting of various island destinations (places, ports and bays) significantly contributed to the change of living conditions on islands in these terms (Žabica [2]):

- Local inhabitants were able to make extra profit (fish sales, catering, other tourist services)

- Local ports and bays became places for raising funds by charging for berths in ports or at regulated anchorages

- Local inhabitants were able to make extra profit by selling food and drinks, etc.

- In wider terms, it can be said that nautical tourism led to the decrease of emigration from the islands because there were more opportunities for finding a job and making profit on the island, and not somewhere else

- Larger opportunities for finding a job had influence on the general increase in the standard of coastal and insular towns, on the increase in families' general welfare, and on creating possibilities for development and revitalization of various activities specific for a particular area. 


\section{Problems of unsystematic development of nautical tourism on the coast and islands}

Along with the series of unquestionable and obvious economic and social benefits that were realized in the development of nautical tourism and its effects in recent decades, such development also led to certain disadvantages.

A short-term negative influence is reflected in excessive crowds caused by too many vessels on unregulated moorings, inadequate moorings in certain destinations, the unregulated and varying attitude of local authorities toward charging for services in ports, little ports and moorings.

The long-term negative effects of unsystematic development of nautical tourism are threats that boaters' interest in visiting the Croatian Adriatic will gradually decrease because of excessive crowds, inadequate quality of supply and exaggerated prices, poor regulation of the system, etc. As a result, the level of attractiveness of the Adriatic Sea, coast and islands will decrease.

Some of the most important direct and indirect negative effects are:

1. Downgrading the environment quality

Downgrading the environment quality is one of the possible disadvantages of the (excessive) development of nautical tourism due to:

- Development of marinas in inadequate places considering natural characteristics of the landscape (marinas Žut and Piškera in "Kornati" National Park - because of the endangerment of the National Park; Marina Šimuni - because of bay pollution due to inadequate sea water exchange; Marina Palmižana - because of downgrading the natural landscape, etc.)

- Increased number of anchorages in bays with inadequate sea airing (Telašćica - because there are too many buoys in the organized anchorage and too many vessels during the season, especially in the back of the bay, which together with daily visits of excursionists from nearby coastal towns in Mir bay lead to excessive crowds and pollution, and significant downgrading of the balance that is expected in a Nature Park; Veli Rat - because there area too many buoys in the protected anchorage; Brgulje - also because there are too many buoys for anchoring, etc.)

- At the peak of the season many towns, famous tourist destinations, are overtaken by anchored and moored boats, which leads to enormous crowds, a significant decrease of navigation and mooring safety, safety of the vessels and their crew members (Hvar town on Hvar island, Pakleni otoci, parts of "Kornati" National Park, Korčula town on Korčula island, etc.).

The above-mentioned problems cannot be solved overnight by the development of additional berths and moorings, or by some new prompt regulation, but it is certain that some environments - such as the abovementioned destinations - could have gradually solved those problems through the years. 


\section{Sea (and coast) pollution}

Sea and coast pollution in particular local waters because of the increased number of vessels without appropriate faecal tanks (waste, bilge and faecal waters).

\section{Insufficient level of system manageability}

Considering the basic characteristics of nautical tourism as a dynamic system that were pointed out at the beginning of this paper (boaters' free movement, beautiful nature, limited capacity, uncoordinated actions and activities, etc.), it is completely understandable that it is impossible to expect complete manageability of a nautical tourism system. If something like that would be possible, it would most probably discourage many boaters from coming to the Croatian Adriatic because of the possible excessive restrictions that could appear. Therefore, it is necessary to establish to what degree it is possible to increase the level of manageability and at the same time not damage those attributes that are valuable for nautical tourism.

4. Occupation of maritime property by the development of capacities for boaters' needs

In some cases, the development (regulation) of "anchorages" on maritime property disabled the usual (common) anchorage because of the existence of buoys and concession "rights" (e.g. Soline bay on Pašman island, Brgulje bay, Premuda, Olib, etc.). Maritime property should remain free, and regulation in the "regulated anchorage" area can be implemented only and exclusively for those concession works in which the concessionaire was allowed to perform and charge for their use. Restrictions should be established in accordance with the total capacity of the particular local waters.

\section{Uncontrolled construction of the coast and coastal area (ports, marinas)}

As a consequence of excessive construction and commercialization, the general level of attractiveness of the Croatian nautical tourist supply - because there are too many vessels, excessive crowds and because of the inability to find a secure and desirable berth - can be more and more associated with negative attributes (excessive crowds, lack of berths, expensiveness...), which can over the long term lead to drop of interest and drop of total economic value of this branch. That practice can also lead to great danger from the viewpoint of ecology, since inappropriate infrastructure in illegal marinas leads to sea pollution (Favro and Saganić [1]).

\section{Excessive commercialization}

During recent decades it can be seen that there was great interest in the development of moorings and marinas, and that this interest is growing, because these things are considered by promoters as profitable investments. In this way, large numbers of moorings and marinas developed, maybe not always in the best locations and not always considering the most suitable type of service or capacity. Because of excessive commercialization, basic resources that nautical tourism is based on, such as natural potential and good service and technical (and other) are worn down. If any of the two above mentioned unities that nautical tourism is based on were significantly downgraded, there is a realistic possibility that the total level of attractiveness of nautical tourism in Croatia will also decrease. 


\section{Parameters of long-term sustainable development of nautical tourism}

Further development of capacities in nautical tourism should be planned respecting the limitations of interactivity requirements and environment protection requirements in accordance with principles of sustainable development, and with respect for the safety of the entire system and each individual inside the system (Favro and Saganić [1]).

Institutions of the previously defined system will direct and control the development, and they will be constantly coordinating it with the partial aims of the counties and local communities. A systematic approach to further development of nautical tourism based on the principles of sustainable development will over the long term be useful not only to the present, but also to future generations.

The Croatian Adriatic area offers great natural, geographical, historical and ethnological diversity that should, together with its specific qualities, be emphasized and offered as recognizable features of a particular location. It can be concluded that the strategic approach to sustainable development of nautical tourism includes the following series of tasks:

- Defining protected areas through one database. These areas will, because of their exceptional value (national parks, nature parks), be defined as areas for daily visits through moorings on organized anchorages and moorings without the possibility of spending the night (Kornati, Krka, Mljet, etc.). By avoiding stationary objects of nautical tourism (marinas, ports), the danger of boaters damaging the environment (oil spills, garbage) will be reduced.

- Evaluating potentially interesting locations on the coast by using multiple-criteria analysis of the particular area.

- Multiple-criteria analysis of gathered data by competent government and professional institutions. That analysis would be the basis for making suggestions for increasing capacities of nautical tourism.

- Multiple-criteria analysis should include:

- Geographical and meteorological characteristics of the location

- Environmental values

- Nautical and navigational characteristics

- Past impacts on the environment and risks

- Infrastructure: electric power, water supply and telecommunications

- Traffic connections

- Coverage by regional plans

- Market demands - areas of intensive nautical tourism

- Possibility for development of complementary activities employment.

The obtained data would determine the potential of a particular area for the development of nautical tourism capacities considering the geographical, maritime, ecological, social and economic characteristics of the location. Wide 
presentation of the obtained data to local communities, holders of preliminary initiatives for development of particular nautical structures (marinas, ports) would be accompanied by acceptance of the general government's orientation as the leader in nautical tourism development. It is necessary to develop maritime cadastre that will include an organized database of the sea, maritime property and coastal area, which would enable high-quality decision making of the most important decisions based on data about the marine area (underwater parks, bottom type, proximity of attractions such as national parks, archaeological monuments, sunken ships, etc.). Based on this maritime cadastre it would be possible to accurately determine rights and obligations of particular local communities and counties for their part of the local waters. An important parameter of the multiple-criteria analysis of coast and islands for determining areas suitable for nautical tourism development should be an exactly defined methodology for determining ecological sensitivity of a particular part of the Croatian Adriatic to impacts by subjects and objects of nautical tourism. It is necessary to determine a methodology of studying and interpretation of defined parameters that would ensure control of the impact that nautical tourism development has on the environment, which is the basic condition for ensuring long-term sustainable development. In spite of nautical tourism development in recent decades, results are not equal to possibilities for its development in Croatia (Favro [4]). A well organized system of nautical tourism on the Adriatic can initiate development of some neglected areas that would, with appropriate evaluation of natural and spatial potential, become attractive for investments (Favro [4]). This would ensure employment and stop further depopulation of rural areas on the coast, and especially on islands.

After the local government has shown interest, and the potential object is coordinated with the county's regional plan with the help of government institutions, the project is made. Initiative and crucial impact in the realization of a particular project (choosing location, choosing the type of capacity: anchorage, mooring, port, marina) is left to local government with the help of the government and ministry through competent government/professional institutions from the area of sea and navigation. The responsibility in choosing investors in the process of invitation for tenders would be under the jurisdiction of local government (district, municipality). Project making and realization of construction would be performed applying acknowledged international standards for categorization of ports of nautical tourism (e.g. Lloyd's) through evaluation of the quality of (Favro [4]):

- technical equipment

- servicing

- burglary/theft/damage safety

- protection from extreme meteorological occurrences, fires, accidents

- possibility of berth in the winter

- additional programs.

During preparations for putting the port of nautical tourism (marina, mooring, anchorage) in operation, the government should define obligatory coordination of the work of particular companies with international standards: Environmental 
management system ISO 14000:2000 and Quality management system ISO $9001: 2000$. This way, controlling the level of quality of a particular subject would be simplified, and controlling the impact on the environment would be ensured. Supervision of good implementation of established standards would be ensured by certificates of authorized international institutions (certification firms), as well as by the existing government's inspection authorities. Navigation safety would be ensured by the Coastguard and Port authorities, and constant control of the ecological situation in particular locations by establishing ECO patrols at the level of local government funded by sojourn taxes (Favro [4]).

\section{Conclusion}

Nautical tourism as a branch of the economy should be developed within the limits of acceptable pressure and recognizable features of the region, relying to a maximum degree on the existence of the preserved and attractive natural environment as an advantage of a Croatian territory. In the process of choosing locations for ports of nautical tourism and tourist ports, multiple developmental effects should be recognized (economic, social, and ecological), as well as those that will set in motion other components of life, that being especially important for strategically sensitive areas, such as, for example, islands. The unharmed or non-industrialized parts of the Croatian coastline, due to which it gained the epithet of an attractive nautical destination, should be protected according to the plan in order not to disrupt the quantitative or qualitative ecological and natural balance of those parts. That balance could be disrupted by construction of reception capacities for boaters' vessels. This means that the future development of nautical tourism should be based on principles of sustainable development. Preservation of natural resources for the purpose of service quality in nautical tourism reflects the condition of the activity, and only the superior quality can represent, over the long term, nautical tourism of the Adriatic ports. The vision of nautical tourism development in Croatia implies reorganization of existing berths in marinas in a way to ensure the maximal number of berths in the existing spatial framework of the marina, as well as constant control of marina operation in consistence with high ecological standards. The systematic approach to further development includes a different organization structure for nautical tourism, offered in order to avoid business moves that could destroy the environment. By organizing the nautical tourism system on the Adriatic on the principles of sustainable development, new criteria for human behaviour in the nowadays very sensitive environment will be established. This will contribute to the coordination of the developmental growth projection of particular marinas with overall developmental projection of nautical tourism in Croatia.

\section{References}

[1] Favro, S. \& Saganić, I., Sustainable Development of Nautical Tourism in Croatia, "New Perspectives and Values in World Tourism \& Tourism 
Management in the Future", Turk-Kazakh International Tourism Conference, Alanya, Turkey, Book 1, pp. 602-620, 2006

[2] Žabica, T., Jadranske turističke regije, Fakultet za turizam i vanjsku trgovinu, Dubrovnik, 2006

[3] Kozak, M. \& Rimmington M., Benchmarketing: Destination Attractiveness and Small Hospitality Business Performance, International Journal of Contemporary Hospitality Management, 10(5), pp. 184-188, 1998

[4] Favro, S., Joining of Croatia in the Development of the European Nautical Tourism, First European Yacht Tourism Congress, Rogoznica, 2002

[5] Favro, S. \& Glamuzina, N., Contemporary problems of Nautical Tourism Development in Croatia, Promet, Portorož, Trieste, Zagreb, 2/2005, pp. 107-112, 2005

[6] Gržetić, Z. \& Favro, S., Systematic approach to the Development of the Nautical tourism in Croatia, $6^{\text {th }}$ Paneuropean Shipping Conference, Split, pp. 103-113, 2005

[7] Kovačić, M. \& Favro, S., Physical Plans in Managing Sea and Coastal Area, $25^{\text {th }}$ International Conference on Organizational Science Development, Portorož, 2006

[8] Kovačić, M., Kesić, B. \& Favro, S., Swot Study of The Nautical Tourism Development in Croatia, $26^{\text {th }}$ International Conference on Organizational Science Development. „Change management“, Portorož, pp. 875-883, 2007

[9] Kozak, M. \& Rimmington, M., Measuring Tourist Destination Competitiveness: Conceptual Consideration and Empirical Findings. International Journal of Hospitality Management, 18(3), pp. 273-283, 1999

[10] Luković, T. \& Favro, S., Strategic and Tactical Plans as Part of Controlling in Marina Management, $6^{\text {th }}$ Paneuropean Shipping Conference, Split, pp. 48-70, 2005

[11] Jadrešić, V., Hrvatski nautički turizam - između danas i sutra, Turizam, vol. 45 No. 11/12, pp. 111-123, 1997

[12] Hydrographic Institute of the Republic of Croatia and partners, Study of nautical tourism development of the Republic of Croatia, Project of the Government of the Republic of Croatia, 2006 